\title{
Welfare State's Redistributive Effect Is Exaggerated
}

\author{
Jan Selén \\ Swedish Institute for Social Research, Stockholm University and Statistics Sweden \\ P O 24300, SE-10451, Stockholm, Sweden \\ E-mail: jan.selen@scb.se
}

Ann-Charlotte Ståhlberg (Corresponding author)

Swedish Institute for Social Research, Stockholm University, SE-106 91, Stockholm, Sweden

Tel: 46-8-163-449 E-mail: ann-charlotte.stahlberg@sofi.su.se

Received: February 14, $2011 \quad$ Accepted: March 8, $2011 \quad$ doi:10.5539/res.v3n1p71

The Swedish Council for Working Life and Social Research and the Swedish Social Insurance Agency supported this work.

\begin{abstract}
This article questions traditional analysis of the redistributive effect of the welfare state and investigates how large the effect would be with a realistic alternative for comparison. The most commonly used reference point is the zero-government counterfactual that measures redistributive effect of social policy against distribution of pre-tax and pre-transfer income. But it is impossible to ignore the fact that some form of transfer is necessary. The elderly and sick, for example, must have their means of support organised in a way other than via the public transfers under investigation. This article shows that when using an adequate alternative for comparison, social policy impact on income distribution is significantly smaller.
\end{abstract}

Keywords: Counterfactual, Inequality, Poverty, Redistribution, Welfare State

\section{Introduction}

This article questions traditional cross-sectional analysis of the redistributive effect of the welfare state. (Note 1) We know that incomes after transfers and taxes are far more evenly distributed than wage incomes. So the most frequently occurring conclusion is that public transfers have a strong income-levelling effect. For example, Timothy Smeeding and Susanna Sandström (2005) report that 82 percent of Sweden's pensioners would have incomes under the poverty line were it not for public pensions, but due to these pensions, the percentage below the line is only 8 percent. The authors claim that the Swedish pension system reduces poverty among the elderly by more than 70 percentage points. The literature abounds with such conclusions. The difference between market income and disposable income is expected to capture the equalising effect of taxes and transfers.

Reynolds and Smolensky (1977) and Brady and Sosnaud (2010) particularly criticise this reasoning. The most commonly assumed counterfactual in the literature is an economy in which there are neither government expenditures nor taxes (the zero-government counterfactual). Smeeding and Sandström (2005) and most others, such as Atkinson (2003) and Pestieau (2006), compare income distribution - including taxes and transfers - with income before taxes and transfers (factor income). All authors are fully aware that factor income depends on taxes and transfers and that labour supply, savings, education, and such probably vary with taxes and transfers; this variation, in turn, has repercussions for the wage and interest-rate structure. (Note 2) But secondary effects are especially difficult to determine. Because of that, ignoring economic behaviour and disregarding the impact of public transfers and taxes on factor income may be acceptable. A very elaborate behavioural model of the economy would be necessary to account for these effects.

Here, we stress a second and different limitation: We question the usefulness of a counterfactual that exists in a situation that totally lacks transfers. If any claim to a minimum of realism is to be made, then we cannot assume that a counterfactual to a welfare state does not provide any protection and ignore the fact that some types of transfers are necessary within society. Individuals cannot live of their labours throughout their lives. In some 
phases, their work capacity is inadequate - childhood, old age, sickness periods, and so on. And sometimes work capacity might exist but cannot be used - unemployment. If analyses of distribution policy effects are taken seriously, then they cannot be based on comparisons with situations in which many persons have no income and means of support. A proper counterfactual must recognise that children, the elderly, the sick, and the unemployed have various means of support, which are organised in a way other than via the investigated public transfers. Remarkably few income distribution studies account for this second limitation. This issue has received less attention than it deserves.

Lampman and Smeeding (1983) consider this problem and question whether the proper counterfactual is one that includes inter-family transfers that occur before public transfers. Björklund (1998) claims that without public support, private pension systems can be reasonably assumed to grow in importance. The proper counterfactual might be a private-market coverage system. But when it comes to empirical studies, we know of only one:Franzén, Lövgren, and Rosenberg (1975). They compared actual redistribution with a counterfactual where taxes, cash transfers, and benefits in kind were proportional to total net income - a concept quite close to disposable income. Söderström's (1988) qualitative analysis of the Swedish social insurance system is in somewhat the same vein but contains no empirical investigation or results. (Note 3) Söderström concludes that Swedish social policy has a progressive effect on income distribution but that this progressive tendency is successively undermined by the increasing priority given to the income loss principle at the expense of the basic social security principle.

If we imagine that the counterfactual is a private transfers system, then the counterfactual could take many forms. Historically, private solutions have primarily been cooperative or collective schemes organised, for example, by local communities, guilds and trade unions. Today, non-cooperative schemes - or schemes offered at market terms by banks and insurance companies - could also make a passable contribution to meeting the need for transfers. A study of the distributive effects of current public transfers does not necessarily require a private alternative for comparison. The counterfactual may also be a public system that is somewhat neutral in terms of redistribution. What is important is that the alternative for comparison is not left blank. Yet the most commonly used reference point is the zero-government counterfactual. These publications, for example, do not address this fundamental issue: Handbook of Income Distribution (2000) and the Oxford Handbook of Economic Inequality (2009).

It is evident that traditional analysis, in which the counterfactual is death from starvation for large groups (the elderly usually have little or no wage income because they rely on public pensions) overrates effects of current taxation and transfer policy, especially in the developed world. The question then is, how large would the effects be with a realistic alternative for comparison? Different societies make different social choices regarding how much equality to pursue and how to pursue it. We would need different counterfactuals for each society.

In this paper Sweden serves as an object lesson to illustrate the importance of not selecting the zero-government counterfactual. Sweden has a relatively large welfare state that provides substantial income-components to substantial portions of society.

The ideal analysis would require a complete study that covers taxes, transfers, and public subsidies in their entirety. Nevertheless, we focus solely on earnings-related public pensions. These pensions constitute a substantial part of public transfers in Sweden as well as in most industrial countries, and also form the largest part of cash benefits.

The article is organised as follows. Section 2 presents the counterfactual. Section 3 presents institutional setting for Sweden. Section 4 describes our method, and section 5 presents our data. Section 6 reports estimations and empirical results. Section 7 concludes.

\section{The counterfactual}

If distributive effects of public transfers are to be specified, then these effects must be based on assumptions of what would have happened to incomes (i) without public transfers or (ii) with public transfers that are structured differently. The crucial issue is that the counterfactual is not left blank.

Here, the counterfactual is (ii); a public system with benefits identical to the real system, but is in some sense neutral in terms of redistribution, i.e., a person's expected benefits are equal to her or his social security contributions. These factors support this contention:

- The actuarial contribution counterfactual system that we suggest (i) closely resembles the type of system that gives the greatest economic effectiveness and (ii) is aligned with current, worldwide, pension system development toward defined contribution systems. Pension systems are being modified in many parts of the 
world. The growing financial pressure of ageing populations makes policies that strengthen the link between individual contributions and benefits particularly important. Indeed, many countries have replaced a defined benefit system with a defined contribution one (either a funded DC or an NDC pension), since ageing populations may make defined benefit schemes financially unstable. In defined benefit schemes, the basis for calculating benefits did not comprise all years' income but only a part of the years in the labour market (best or final years) while pension contributions were proportional to all income.

- The private insurance market could suffer from adverse selection problems, so most people might perceive that they are better off under a public system (see for example Barr 1992).

- In Sweden, practically all wage earners have another collective-agreement-regulated pension, besides the state pension, which raises their total pension level. These added benefits are the result of negotiations between labour market participants (trade unions and employers associations) and are entirely voluntary and independent of state authority. Everyone working for an employer who has signed a collective agreement automatically has the coverage that has been agreed upon. Less than 10 per cent of the total workforce works in companies that do not have such an agreement. Even though this is not optional for wage earners and employers covered by the agreements there is very low probability that the parties would negotiate on something not wanted by the majority. Many persons also choose to augment their pensions through private savings. So it is unlikely that actual social security benefits are higher in Sweden than individuals would have chosen.

By letting the counterfactual include unaltered public coverage, crowd-out effects on private saving will not occur in the study.

\section{Institutional setting for Sweden}

Both the social insurance and the tax systems are based on the individual and offer neither tax relief nor special allowances for a spouse working in the home. Social insurance is not responsible for survivor's pensions.

Before 1998, Sweden's public pension system was a defined benefit system with (i) a flat-rate benefit that is not linked to previous income (national basic pension) and (ii) an earnings-related benefit (national supplementary pension). A special pension-tested supplement was also paid to persons with low or no earnings-related pensions. The combined basic pension and supplementary pension normally made up about 60 percent of an individual's 15 years of highest covered earnings (earnings up to a ceiling); here, 30 years of work was necessary for full pension. Via payroll taxes levied on employers, these benefits were mainly financed on a pay-as-you-go basis.

In 1998, new Swedish pension legislation mandated a gradual transition from a public-defined benefit scheme to a public-defined contribution plan. The new pension system is a notional-defined contribution system with a small funded component; 16 percent of covered earnings is credited to the notional account. The remaining 2.5 percent of covered earnings is contributed to a self-invested personal pension. Besides earnings-related benefits, the pension system includes a guaranteed minimum pension, which pays a supplement on top of the annuities from the notional and funded accounts - if their sum falls below a certain level. General tax revenues finance the minimum pension. During a transition period, benefits are paid from both systems. (Note 4)

\section{The method}

This section covers:

- What individuals pay for social insurance benefits - the burden

- Actuarially fair contribution

- Swedish conditions in 1995 and 2005 constitute the starting point

\subsection{What individuals pay for social insurance benefits}

Payroll taxes, which are levied as a fixed percentage of the total wage bill, are mainly used to finance pensions and other forms of cash insurance benefits such as sickness benefits, life annuities from occupational injury insurance schemes, and unemployment insurance. To varying degrees, the payroll taxes burden can be shifted from those who bear formal responsibility for payment. This burden can be shifted backward onto wage earners so that real wages are lower than they would be otherwise. Or payroll taxes can be shifted forward onto consumers in the form of higher prices. For public sector employees, a forward shift in the payroll tax burden would mean an equivalent increase in other taxes. In small open economies, such as Sweden's, payroll taxes are largely shifted backward onto wage earners in the long term (for empirical support, see Palmer and Palme 1989). In this way, companies in such economies avoid being placed at a competitive disadvantage when they compete on international markets. 
Given this assumption, the burden of the payroll tax can be described as follows. Let $Y_{i, t}=$ individual $i$ 's annual pre-tax wage income a specific year $t, q_{t}=$ the payroll tax for social security benefits year $t$. If payroll tax did not exist, then individual $i$ 's pre-tax wage income would be $q_{t} \times Y_{i, t}$ higher. The payroll tax abolition increases the tax base for income taxation. If conditions are to otherwise remain the same, then the increase must be compensated for by a cut in the average rate of income tax. Before "the change" individual $i$ 's tax contribution is $Y_{i, t} \times T_{t}$ where $T_{t}$ is the average rate of income tax. After "the change" his or her tax contribution is $Y_{i, t} \times T_{t}^{\prime}+q_{t}$ $\times Y_{i, t} \times \tau^{\prime}\left(Y_{i, t}\right)$ where $T_{t}^{\prime}$ is the new average rate of income tax on the original income and $\tau^{\prime}\left(Y_{i, t}\right)$ is the new marginal tax rate. The individual's total tax contributions are to be the same "before" and "after" why $Y_{i, t} \times T_{t}=$ $Y_{i, t} \times T_{t}^{\prime}+q_{t} \times Y_{i, t} \times \tau^{\prime}\left(Y_{i, t}\right)$.

We assume that $T_{t}$ and $\tau\left(Y_{i, t}\right)$ change uniformly so that $T_{t}^{\prime}=T_{t} / \mathrm{c}$ and $\tau^{\prime}\left(Y_{i, t}\right)=\tau\left(Y_{i, t}\right) / c .\left(\tau\left(Y_{i, t}\right)\right.$ is the original marginal tax rate). Then the constant $\mathrm{c}$ is equal to: $\mathrm{c}=1+q_{t} \times \tau\left(Y_{i, t}\right) / T_{t}$. The net effect of payroll tax abolition on disposable wage income is obtained by adding $Y_{i, t} \times\left(T_{t}-T_{t} / \mathrm{c}\right)$ - payroll tax burden after income tax reduction - to $q_{t} \times Y_{i, t} \times\left(1-\left[\tau\left(Y_{i, t}\right) / \mathrm{c}\right]\right.$ - payroll tax burden after net wage increases. The sum represents the burden of what individuals pay for social security benefits.

Basic social security under the old system consisted of the basic pension, which was paid out to all in equal amount, along with the additional pension benefit, which was a means-tested supplement for those with a low or no earnings-related benefit. Basic social security under the new system is the minimum guaranteed pension, which is means-tested against public pension from income. If we assume that the aggregated means-tested supplement is not affected by the counterfactual, then the tax rate that finances the minimum level is the same as the actual. This is a simplification that we do not perceive to be of crucial importance for the analysis.

\subsection{The actuarially fair contribution}

The actuarially fair contribution $\left(\mathrm{C}_{i, t}\right)$ for individual $i$ in an earnings-related defined benefit pension scheme is equal to the annual accrual in the expected present value of his or her pension liabilities $\left(P_{i, t}\right)$. It may be determined as follows. Let $L_{i, t}=$ individual $i$ 's annual pension benefits earned up to year $t, A=A_{i, t}=i$ 's age at $t$, $D=$ maximal age, $\mathrm{N}=$ age at retirement, $\mathrm{S}_{\mathrm{A}, \mathrm{N}}=$ the probability of surviving from age A to age $\mathrm{N}$, where $\mathrm{S}_{\mathrm{A}, \mathrm{N}}$ (Note 5) varies between men and women, and $r=$ the real rate of discount. Then

$$
C_{i, t}=P_{i, t}=\left(L_{i, t}-L_{i, t-1}\right) \times S_{A, N} \times\left[1 /(1+r)^{N-A}\right] \times \sum_{j=N}^{D} S_{N, j} \times\left[1 /(1+r)^{j-N}\right]
$$

In the calculations below we let $\mathrm{N}=65 ; \mathrm{r}=0.02$ (Note 6)

When the earnings-related pension is defined contribution, then

$\mathrm{C}_{i, t}=\mathrm{q}_{P, t} \times \mathrm{Y}_{i, t}$

where $\mathrm{q}_{P, t}=$ the pension contribution.

\subsection{Swedish conditions in 1995 and 2005 constitute the starting point}

The actuarially fair pension contribution, $C_{i, t}$ when $t=1995$, is equal to

$C_{i, t}=P_{i, t}$

The actuarially fair pension contribution, $C_{i, t}$ when $t=2005$, and $z_{i}$ is the share of the old system and $y_{i, t}$ is covered earnings, is equal to

$C_{i, t}=z_{i} \times P_{i, t}+\left(1-z_{i}\right) \times q_{P, t} \times y_{i, t}$

We determine:

I. The distribution of current annual pre-tax wage income, $\mathrm{Y}_{i, t}$

II. The distribution of current annual disposable income, $\left(\mathrm{Y}_{i, t}+\mathrm{Tr}_{i, t}\right) \times\left(1-\mathrm{T}_{i, t}\right)$, where $\mathrm{T}_{i, t}$ is tax on wage income and benefits and $\mathrm{Tr}_{i, t}$ is benefits from the social insurance system, such as pensions, sickness benefits, and unemployment benefits. We excluded tax-free allowances such as child benefits, student allowances, and housing allowances.

III. The distribution when the counterfactual is a public system whose benefits are identical with the actual system, but financed by actuarial fair contributions,

$$
\begin{aligned}
& \left.\left(\mathrm{Y}_{i, t}+\operatorname{Tr}_{i, t}\right) \times\left[1-\mathrm{T}_{i, t}\right)\right]+Y_{i, t} \times\left(T_{t}-T_{t} / \mathrm{c}\right)+q_{t} \times Y_{i, t} \times\left(1-\left[\tau\left(Y_{i, t}\right) / \mathrm{c}\right]\right)-\mathrm{C}_{i, t} \times\left[1-\tau\left(Y_{i, t}\right) / \mathrm{c}\right] \\
& C_{i, t}=0 \text { for } \mathrm{A}_{\mathrm{i}, \mathrm{t}} \geq \mathrm{N} \\
& \mathrm{q}_{\mathrm{q}, t}=0 \text { for } \mathrm{A}_{\mathrm{i}, \mathrm{t}} \geq \mathrm{N}
\end{aligned}
$$




\section{Data}

For the estimation of various income distributions, we use the 1995 and 2005 Income Distribution Surveys (Statistics Sweden). The Income Distribution Survey is conducted annually and is based on national samples of adults ages $18+$. Information is collected from interviews and administrative data registers and tax return forms. In addition, the total income history of relevance for the pension system is known for each individual, as per income data and the National Social Insurance Agency's data. More than 17,000 households and more than 35,000 individuals are in the annual survey.

For an accurate computation of taxes and marginal taxes under varying assumptions, we use FASIT - Statistics Sweden's tax-benefit computer model.

Our variables are based on (I) income from employment and self-employment, in cash as reported to the tax agency by employers (annual wage income), (II) disposable income that is wage income plus transfers (excluding tax free allowances) minus taxes on wage income and benefits - regarding employment and self-employment, and (III) counterfactual income as outlined above.

\section{Estimation and results}

We compare the different income variables by their distributions. Figures 1 and 2 show estimated smoothed distributions of wage income (I), disposable income (II) and counterfactual income (III), for 1995 and 2005 respectively. The large differences between I and the two other distributions stand out, indicating that the difference between disposable income and counterfactual income indeed is smaller than that between disposable income and wage income. These results are in line with our presumption, which is further supported by the inequality measures shown in table 1. Here estimates for the Gini index, Ricci-Lindahl's equality measure are given as well as medians, decile ratios, and poverty rates.

\section{Insert Figure 1 Here}

\section{Insert Figure 2 Here}

\section{Insert Table 1 Here}

The empirical result for Sweden thus is that when using an adequate alternative for comparison, then the impact of public policy on income distribution is substantially smaller than otherwise. The Gini coefficient for wage income in 1995 is 0.59 , for disposable income, 0.31 and for counterfactual income, 0.32 . So the difference in income equality measured by Gini coefficients is 2 percentage points rather than 28 percentage points. For 2005, it is 2 percentage points instead of 26 . Hence, the redistributive effect of the welfare state has been thoroughly exaggerated.

\section{Conclusion}

Here we have argued in favour of a non zero-government counterfactual. On the basis of the chosen social security alternative and our assumptions regarding the incidence of payroll taxes we have determined the effect on income distribution. If payroll taxes had not exist the gross income, the marginal tax rate and the net disposable income would have been higher. The tax base for income taxation would have increased. When conditions are otherwise to remain the same, this is compensated for by a cut in the average rate of income tax. It is assumed that the alternative system of social protection is based on a public system that is mainly financed by means of actuarial premiums. Based on register data for Sweden 1995 and 2005 respectively, we estimated the counterfactual net income and with this the redistributive effect of the social security system.

By this we illustrated the importance of not selecting the zero-government counterfactual but rather a more proper counterfactual when studying the welfare state's redistributive effects. That Swedish pensioners would have incomes below the poverty line - were it not for current public pensions - is not a true statement. And note that an (more) appropriate counterfactual would result in significantly lower effects. Even though the counterfactual is specific to the Swedish case and in general is only one of many counterfactuals that can be chosen the solution demonstrated how fundamentally misleading the blank counterfactual might be. The long tradition that simply compares actual distribution of disposable income with distribution of pre-tax and pre-transfer income might not yield a reasonable approximation to the proper counterfactual.

\section{References}

Atkinson, T. \& Bourguignon, F. J. (2000). Handbook of Income Distribution Volume I. Amsterdam: North Holland. 
Atkinson, T. (2003). Income Inequality in OECD Countries: Data and Explanations. CESifo Economic Studies, 49 (4), 479-513. [Online] Available: http://www.cesifo-group.de/DocCIDL/cesifo_wp881.pdf.

Barr, N. (1992). Economic Theory and the Welfare State: A Survey and Interpretation. Journal of Economic Literature, 30, 741-803.

Björklund, A. (1998). Income Distribution in Sweden: what is the achievement of the welfare state? Swedish Economic Policy Review 5, 39-80. [Online] Available: http://www.sweden.gov.se/sb/d/574/a/95439.

Brady, D. \& Sosnaud, B. (2010). The Politics of Economic Inequality. In K. T. Leicht \& J.C. Jenkins (Eds.). Handbook of Politics: State and Society in Global Perspective, (pp. 521-541). Handbooks of Sociology and Social Research. Springer. doi: 10.1007/978-0-387-68930-2_28, http://dx.doi.org/10.1007/978-0-387-68930-2_28

Chetty, R. \& Saez, E. (2009). Teaching the tax code: earnings responses to an experiment with EITC recipients, Working Paper 14836, National Bureau of Economic Research. [Online] Available: http://www.nber.org/papers/w14836.

Franzén, T., Lövgren, K. \& Rosenberg, I. (1975). Redistributional Effects of Taxes and Public Expenditures in Sweden. Swedish Journal of Economics, 77, 31-55.

Lampman, R. J. \& Smeeding, T. (1983). Interfamily Transfers as Alternatives to Government Transfers to Persons. Review of Income and Wealth, 29(1):45-66. doi:10.1111/j.1475-4991.1983.tb00631.x, http://dx.doi.org/10.1111/j.1475-4991.1983.tb00631.x

Palmer, E. \& Palme, M. (1989). A Macroeconomic Analysis of Employer-Contribution Financed Social Security. In B. Gustafsson \& A. Klevmarken (Eds.). The Political Economy of Social Security (pp. 113-142). Amsterdam: North-Holland.

Pestieau, P. (2006). The Welfare State in the European Union - Economic and Social Perspectives. Oxford, New York: Oxford University Press.

Reynolds, M. \& Smolensky, E. (1977). Public Expenditures, Taxes, and the Distribution of Income. New York, San Francisco, London: Academic Press.

Salverda, W., Nolan, B. \& Smeeding, T. (2009). The Oxford Handbook of Economic Inequality. Oxford: Oxford University Press.

Smeeding, T. \& Sandström, S. (2005). Poverty and Income Maintenance in Old Age: A Cross-national View of Low Income Older Women, Luxembourg Income Study Working Paper Series 398.

Söderström, L. (1988). The redistribution effects of social protection: Sweden. In: J-P. Jallade (Ed.). The crisis of redistribution in European welfare states (pp. 73-144). European Institute of Education and Social Policy: Trentham Books.

SOU. (1997). Official investigation, Stockholm, 166. [Online] Available: http://www.sweden.gov.se/sb/d/392/a/25099.

Notes

Note 1. Cross-sectional analysis is the predominant method applied in studies of how taxes and transfers redistribute resources among individuals and households in any given year. The most common way to compare incomes among individuals is to run a comparison for a specified year. Another way is to compare individuals' lifetime incomes or to compare cohorts' (generations') incomes. But then the analyses become much more complicated because they require that we acquire income data for more than one single year. To acquire lifetime income data, we must either wait until a person dies or we must simulate the person's lifetime income.

Note 2. Given that individuals are fully informed about government policies relevant for their choices (Chetty \& Saez 2009).

Note 3. Nonetheless, his study inspired our work.

Note 4. Those born in 1937 or earlier get their old-age pensions as per the old system. The new system will totally cover those born in 1954 or later. Those born between 1938 and 1953 will have one share from the old system and one from the new system; here, older people will have a larger share from the old system than younger people.

Note 5. Studies show that an individual's mortality risk depends on social position so that persons in higher social classes have lower risk of premature death. One Swedish study from 1997 (SOU: 1997) shows that 
blue-collar workers, who have reached age 60, have a life expectancy that is 1.5 to 2 years shorter than white-collar workers of the same age. But differences between women and men are far greater than observed differences between social classes. When mortality risk is diversified only according to age and sex, then we overestimate pension premiums of blue-collar workers and underestimate those of white-collar workers.

Note 6. The real rate of discount is assumed to be 2 percent, a reasonable assumption in view of the fact that the average growth in the past 100 years has remained constant at about that level.

Table 1. Income characteristics

\begin{tabular}{|c|c|c|c|c|c|c|c|}
\hline & \multirow{2}{*}{$\begin{array}{l}\text { Median } \\
\text { thousands, } \\
\text { Skr. }\end{array}$} & \multicolumn{3}{|c|}{ Decile ratios } & \multirow[t]{3}{*}{ Gini } & \multirow[t]{3}{*}{ Ricci-Lindahl } & \multirow{3}{*}{$\begin{array}{l}\text { Poverty } \\
\text { index }\end{array}$} \\
\hline & & $8 / 2$ & $7 / 3$ & $6 / 4$ & & & \\
\hline \multicolumn{5}{|c|}{1995} & & & \\
\hline wage income & 68 & $\mathrm{x}$ & $\mathrm{x}$ & 7.86 & 0.592 & 0.457 & 0.442 \\
\hline disp.income & 100 & 2.67 & 1.78 & 1.30 & 0.307 & 0.214 & 0.165 \\
\hline cf. income & 99 & 2.83 & 1.88 & 1.33 & 0.323 & 0.226 & 0.167 \\
\hline \multicolumn{8}{|c|}{2005} \\
\hline wage income & 121 & $\mathrm{x}$ & $\mathrm{x}$ & 4.96 & 0.575 & 0.441 & 0.428 \\
\hline disp.income & 149 & 2.64 & 1.75 & 1.29 & 0.314 & 0.217 & 0.165 \\
\hline cf. income & 145 & 2.83 & 1.87 & 1.37 & 0.333 & 0.231 & 0.183 \\
\hline
\end{tabular}

${ }^{1}$ Fraction below half the median.

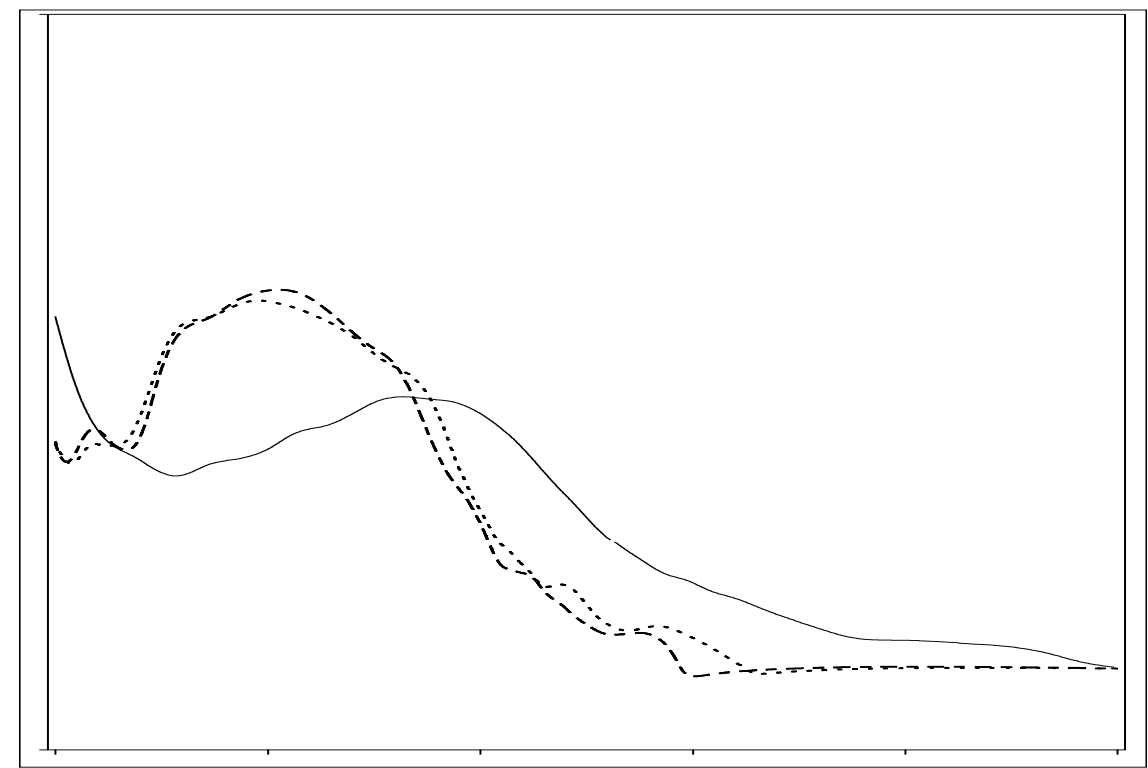

Figure 1. Income distributions 1995, individuals. Smoothed distributions

Tick marks for $100000 \operatorname{Skr}(0,100000,200000, \ldots 500000)$

Wage income (I): solid line

Disposable income (II): dashed line

Contrafactual income (III): dotted line

Logarithmic scale for the vertical axis 


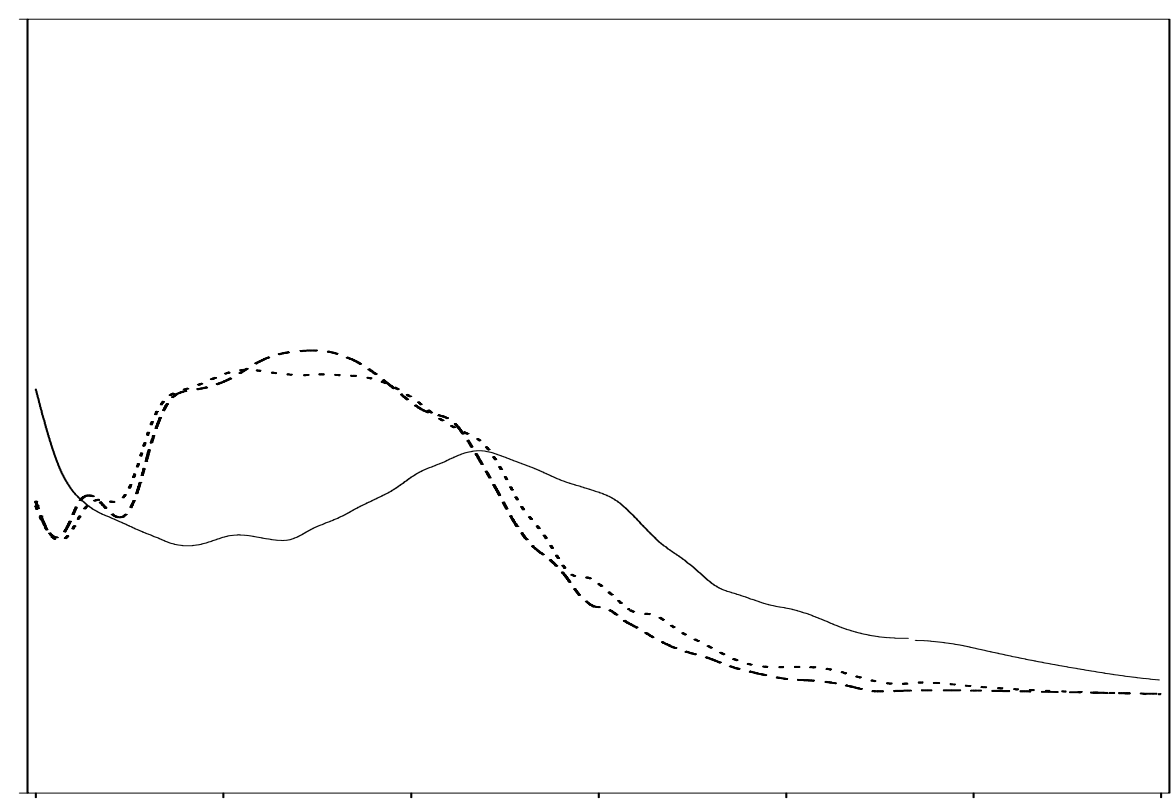

Figure 2. Income distributions 2005, individuals. Smoothed distributions

Tick marks for $100000 \operatorname{Skr}(0,100000,200000, \ldots 600000)$

Wage income (I): solid line

Disposable income (II): dashed line

Contrafactual income (III): dotted line

Logarithmic scale for the vertical axis 